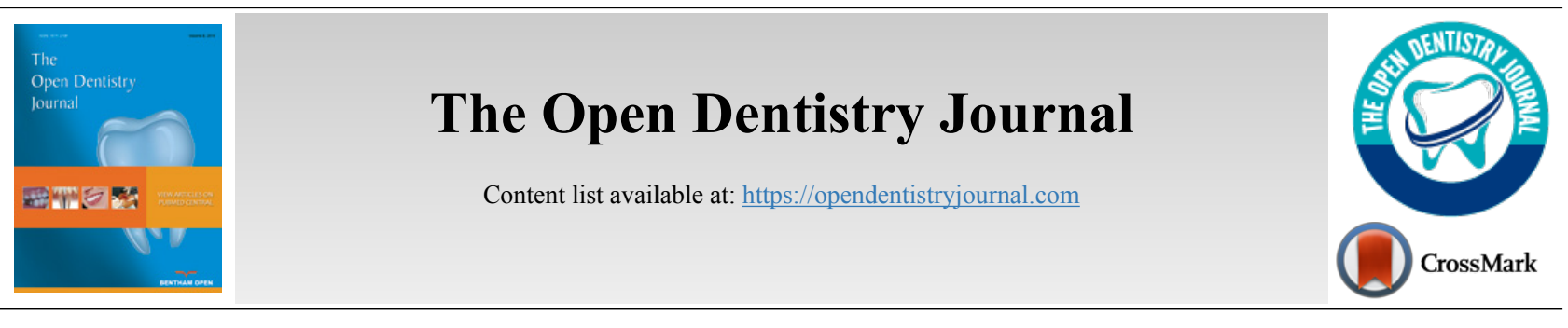

RESEARCH ARTICLE

\title{
Debonding Shear Strength of Orthodontic Tubes Bonded to Skeletal Anchorage Miniplates with Different Agents
}

Lucas Da Silva Meirelles ${ }^{1}$, Orion L. Haas ${ }^{1, *}$, Neimar Scolari ${ }^{1}$, Mauricio Pereira ${ }^{1}$, Andre Favoretto ${ }^{1}$ and Rogério de Oliveira ${ }^{1}$

${ }^{1}$ Department of Oral and Maxillofacial Surgery, Pontifical Catholic University of Rio Grande do Sul, Porto Alegre, Rio Grande do Sul, Brazil

\begin{abstract}
:
Introduction:

Most miniplates used for skeletal anchorage lack built-in orthodontic devices. To address this issue, orthodontists must use creative solutions, such as bonding buttons, brackets, or tubes directly to the miniplates, thus making them more versatile devices that provide a wider range of tooth movement possibilities. The purpose of the present study was to ascertain the debonding strength in Megapascals (MPa) of orthodontic accessories bonded to skeletal anchorage miniplates with different bonding agents.

Methods:

Forty specimens were divided into two equal groups by bonding agent: Group 1, resin (Transbond XT ${ }^{\circledR}, 3 \mathrm{M}$ ESPE); Group 2, cyanoacrylate (Scotchbond $^{\circledR}, 3 \mathrm{M}$ ESPE). Shear strength testing was performed in an EMIC DL-2000 universal testing machine.

Results:

The results obtained were 2.28 $\pm 0.44 \mathrm{MPa}$ for Group 1 and $4.90 \pm 0.76 \mathrm{MPa}$ for Group 2. The Kolmogorov-Smirnov test was used to assess the normality of data distribution. Student's t-test was used to compare means in the response variable.

Conclusion:

A statistically significant difference was observed between groups. However, both bonding agents provided strength in excess of that needed for secure orthodontic tooth movement.
\end{abstract}

Keywords: Orthodontic anchorage procedures, Orthodontic tooth movement, Shear strength, Orthodontic tubes bonded, Titanium miniplates, Tooth movement.

\begin{tabular}{|l|l|l|l|}
\hline Article History & Received: August 21, 2019 & Revised: October 17, 2019 & Accepted: December 18, 2019 \\
\hline
\end{tabular}

\section{INTRODUCTION}

The concept of implants as orthodontic anchorage devices has been studied for over 30 years [ 1 - 3]. Absolute anchorage refers to a fixed, immobile skeletal anchor placed within the oral cavity that allows orthodontic tooth movement without compromising the teeth themselves. Titanium miniplates and screws are widely used in oral and maxillofacial surgery, and have established predictability and biocompatibility [4]. The use of these devices for temporary skeletal anchorage is a relatively new practice, and has become a topic of great interest in orthodontics.

Temporary anchorage was developed by Umemori and

* Address correspondence to this author at the Department of Oral and Maxillofacial Surgery, Pontifical Catholic University of Rio Grande do Sul, Porto Alegre, Rio Grande do Sul, Brazil, Email: olhj@hotmail.com
Sugawara, who were the first to employ titanium miniplates for this purpose [5]. In 2002, de Clerck developed the zygoma anchorage system, which uses the same principles and employs a straight plate and three screws [6].

The efficacy of skeletal anchorage with miniplates has been demonstrated for intruding posterior teeth, closing anterior open bites, distalizing maxillary molars, and retracting/intruding incisors, as well as for individual tooth movement when no other satisfactory anchorage is available [5, 7 - 9].

However, most anchorage miniplates lack built-in orthodontic devices. Therefore, orthodontists must develop creative adaptations to achieve proper orthodontic forces and the desired tooth movement when using skeletal anchorage devices. One such solution involves bonding buttons, brackets, or tubes directly to the ends of miniplates, thus making them 
more versatile devices that provide a wider range of tooth movement possibilities. However, the methods used by orthodontists to bond these accessories to anchorage miniplates and the strength of this bond are entirely empirical. There is no literature on the debonding shear strength of orthodontic devices bonded to miniplates.

The purpose of this study was to conduct an in vitro mechanical assay to ascertain which bonding agent provides the highest debonding shear strength when used to bond orthodontic tubes to skeletal anchorage miniplates.

\section{METHODS}

\subsection{Resin Embedding of Skeletal Anchorage Miniplates}

The sample consisted of 40 specimens divided into two equal groups.

According to the bonding agent employed. Group 1: Resin (Transbond $\mathrm{XT}^{\circledR}, 3 \mathrm{M}$ ESPE) - 20 specimens; Group 2: Cyanoacrylate (Scotchbond ${ }^{\circledR}$, 3M ESPE) - 20 specimens. Embedding of the skeletal anchorage miniplates in composite resin was performed in a jig consisting of a metal cylinder composed of one inner and one outer part. The inner part consists of a split cylinder $16 \mathrm{~mm}$ in height with a step-shaped recess at one end. This recess creates a difference in internal diameter, which is $20 \mathrm{~mm}$ in the portion of the cylinder above the recess and $16 \mathrm{~mm}$ in the remaining portion. Hence, the acrylic resin base specimens cast in this jig will have a stepped base, which can be used to clamp them to the testing machine during the tensile strain assay. The outer part has an inner diameter of $23 \mathrm{~mm}$ and a height of $16 \mathrm{~mm}$. It includes four equidistant threaded holes through which screws are driven to secure the mating inner part (Fig. 1).

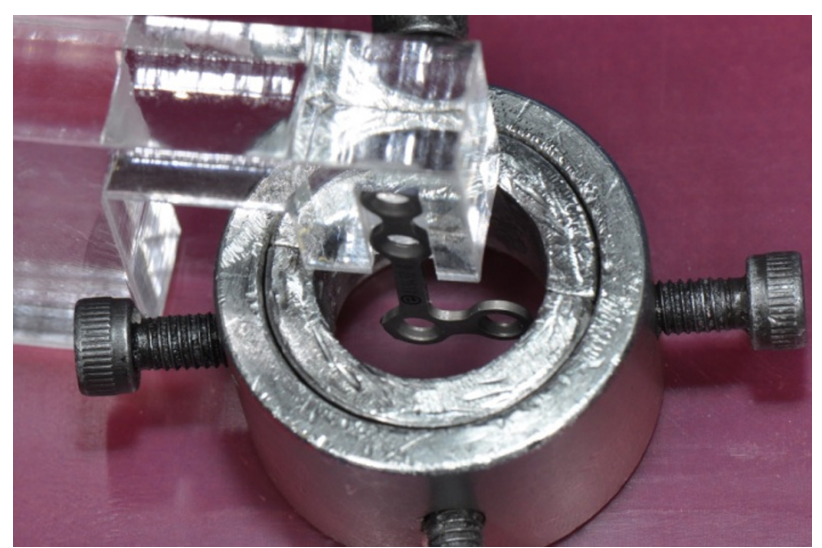

Fig. (1). Miniplate secured in acrylic jaw and positioned at center of metal jig for resin embedding.

Each miniplate (Engimplan ${ }^{\circledR}$, Rio Claro, SP, Brazil) was held with the two links corresponding to the head portion of the miniplate secured in an acrylic jaw (Fig. 2). The specimen preparation procedure was based on that employed in a similar previous study by Menezes et al., [10], and was meant to ensure that the exposed ends of each specimen miniplate were positioned at the same height, centered within the jig and perpendicular to the acrylic base, for debonding shear stress testing. The inner part of the jig was lubricated with petroleum jelly, slid into the outer cylinder, locked in with screws, and placed onto a baseplate wax sheet so that the arm was at the center of the jig (Fig. 3). Then, the jig was completely filled with Jet $^{\circledR}$ acrylic self-curing resin (Clássico, São Paulo, SP, Brazil) in the sandy stage. Once the curing time had elapsed, each resin-embedded miniplate was removed from the jig and stored in a plastic bottle filled with room-temperature distilled water.

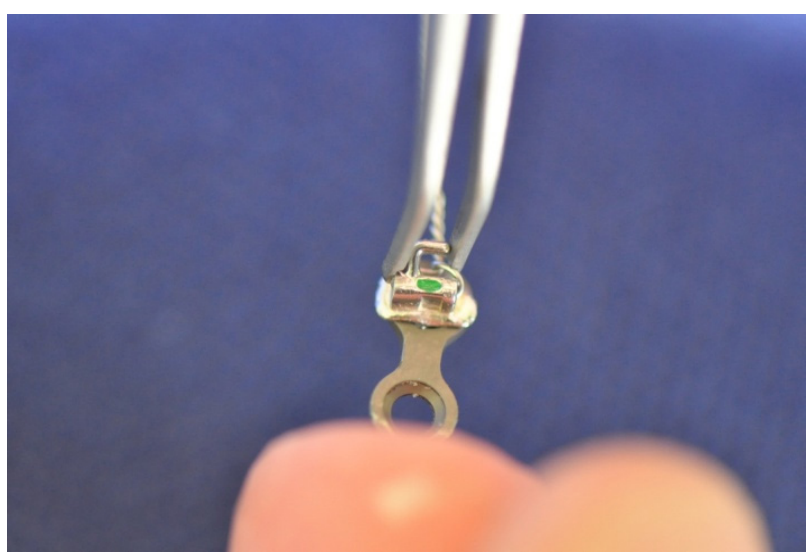

Fig. (2). Resin poured into jig.

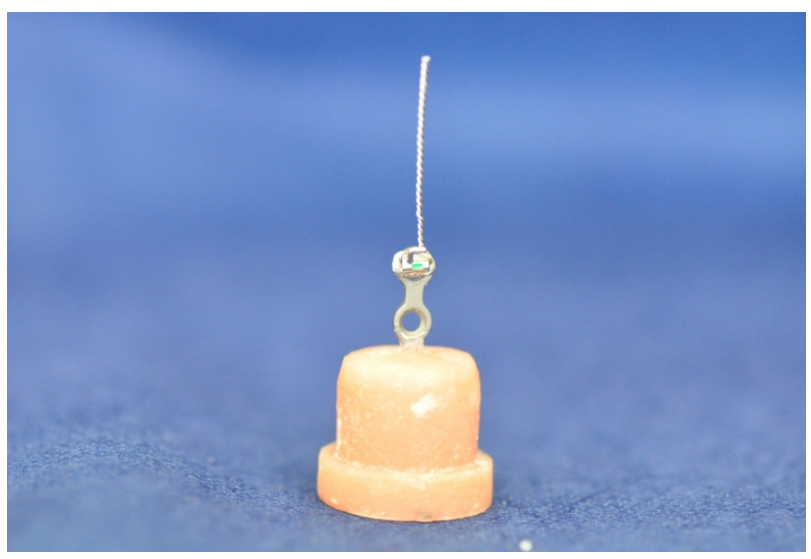

Fig. (3). Tube bonded into resin-embedded miniplate.

\subsection{Orthodontic Tubes}

A 6" Mayo-Hegar needle holder with tungsten carbide inserts $\left(\right.$ Quinelato $^{\circledR}$ ) was used to braid Aciflex ${ }^{\circledR} \# 1$ wire (Ethicon, Johnson \& Johnson), which was then passed through direct bond tubes (American Orthodontics ${ }^{\circledR}$, Sheboygan, WI, USA) until it was flush with the wire-tube interface.

\subsection{Tube Bonding}

For this stage of the experiment, the sample was divided into two groups according to the bonding agent used. All samples were prepared by the same operator. The number of specimens was defined in Minitab 17.1.0 (Minitab Inc. ${ }^{\circledR}$, State College, Pennsylvania, USA), with a view to the normal distribution of the variables of interest. The statistical power of 0.8 was stipulated to detect a minimum difference of 1.090 $\mathrm{MPa}$ between mean shear strength values, with a standard deviation of $1.194 \mathrm{MPa}$ and a significance level (alpha) of 5\%. The parameters used for sample size calculation were obtained 
from a pilot study performed before the experiment.

GROUP 1: Resin (Transbond $\mathrm{XT}^{\circledR}, 3 \mathrm{M}$ ESPE) - 20 specimens

After cleaning each miniplate with $70 \%$ alcohol and drying the exposed miniplate link with compressed air, a layer of composite resin was applied to fill the base of the tube, which was then positioned on the miniplate. Bonding was performed in accordance with manufacturer instructions, using clamps (Hartzell \& Son ${ }^{\circledR}$, Germany), providing enough hand pressure to ensure proper placement and facilitate outflow of excess resin, which was removed with a \#5 dental explorer (Duflex ${ }^{\circledR}$, Brazil). Care was taken during this procedure to prevent complete coverage of the superior and lateral portions of the miniplate or orthodontic tube with resin. The specimen was then light-cured in accordance with manufacturer instructions.

GROUP 2: Cyanoacrylate (Scotchbond ${ }^{\circledR}, 3 \mathrm{M}$ ESPE) - 20 specimens

After cleaning each miniplate with $70 \%$ alcohol and drying the exposed link with compressed air, the miniplate was bonded to the orthodontic tube with two drops of medium-thick cyanoacrylate instant adhesive. The adhesive was applied to the base of the tube, which was then positioned as desired onto the miniplate with the aid of clamps and held in place with hand pressure, to facilitate outflow of excess resin, which was removed with a dental explorer. Again, care was taken to prevent complete coverage of the superior and lateral portions of the miniplate or orthodontic tube with cyanoacrylate.

\subsection{Mechanical Testing}

Shear stress testing was performed in an EMIC DL-2000 universal testing machine (EMIC, São José dos Pinhais, PR, Brazil) coupled to a workstation running MT teste 100 software. The specimen was placed in a metal sleeve attached (Fig. 4) to the base of the universal testing machine, while the crosshead was attached to Aciflex \#1 wire (Fig. 5). The moving crosshead was placed on the top bracket, coupled to a $500 \mathrm{~N}$ load cell, and positioned manually at the same distance for all test specimens.

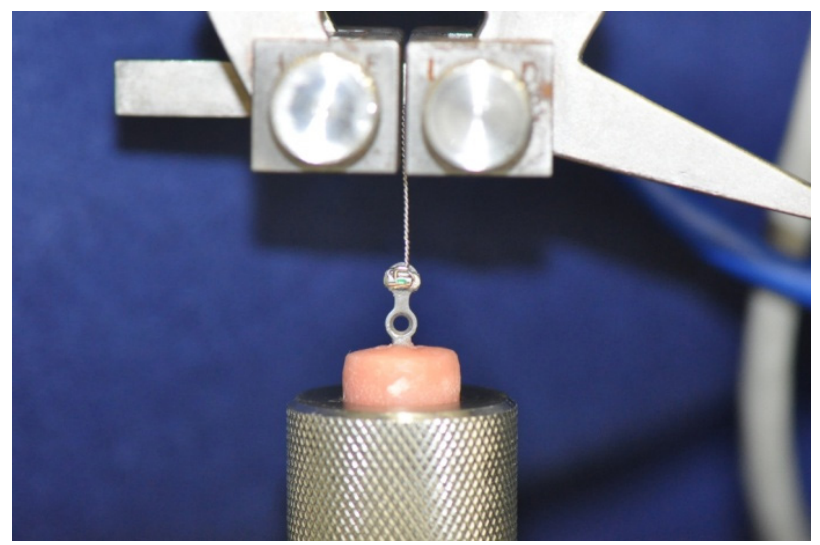

Fig. (4). Speciem secured in sleeve and moving crosshead attached to wire for mechanical testing In all specimens, the bond (joint) failed rather than the material, which is justified by the lack of mechanical retention at the miniplate and by the presence of micromechanical retention at the base of the tube. The present experiment was performed with whole miniplates. However, in clinical practice, retentions could be added to increase debonding strength.

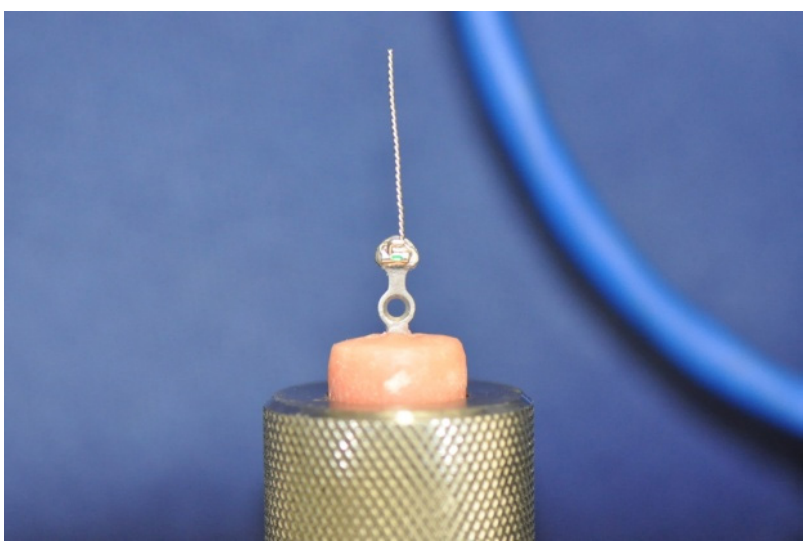

Fig. (5). Speciem secured in sleeve and moving crosshead attached to Aciflex \#1 wire.

The testing machine was actuated by MT teste 100 software. At the appropriate command, the debonding shear strength test was begun at a constant crosshead speed of 0.5 $\mathrm{mm} / \mathrm{min}$ and continued until the bond between anchorage miniplate and orthodontic tube failed.

\subsection{Statistical Analysis}

The Kolmogorov-Smirnov test was used to assess the normality of data distribution. As the data were found to be normally distributed, the parametric Student's $t$-test was used to compare means in the response variable (shear strength).

The significance level was set at $5 \%(p=0.05)$, with $95 \%$ confidence intervals.

\section{RESULTS}

According to the Kolmogorov-Smirnov test, data followed a normal distribution $(p=0.238)$ (Table 1). Student's $t$-test for independent samples was used for comparisons.

Debonding shear strength varied within both the resin and cyanoacrylate groups. In the resin group, debonding strength ranged from a minimum of $1.42 \mathrm{MPa}$ to a maximum of 3.17 $\mathrm{MPa}$. In the cyanoacrylate group, debonding strength ranged from 3.62 MPa to 7.01 MPa. The mean was $2.28 \mathrm{MPa}(\mathrm{SD} \pm$ $0.44)$ in Group 1 versus $4.90 \mathrm{MPa}(\mathrm{SD} \pm 0.76)$ in Group 2 (Table 2), (Fig. 1). Student's $t$-test endorsed a statistically significant between-group difference $(p<0.001)$.

Table 1. Test for normality of outcome variable distribution $(\mathrm{n}=40)$.

\begin{tabular}{|c|c|c|c|}
\hline Variable & Mean \pm SD & Kolmogorov-Smirnov Z & $\boldsymbol{p}$-value* \\
\hline Transbond XT & $2.2794 \pm$ & & \\
& 0.76335 & 1.03 & 0.23 \\
Cyanoacrylate & $\begin{array}{c}4.8982 \pm \\
0.43763\end{array}$ & & \\
\hline
\end{tabular}


Table 2. Comparison of debonding shear strength (MPa).

\begin{tabular}{|c|c|c|c|c|c|c|}
\hline \multirow[t]{2}{*}{ Group } & \multirow{2}{*}{$\begin{array}{l}\text { Mean } \\
\pm \text { SD }^{\dagger}\end{array}$} & \multicolumn{2}{|c|}{$\begin{array}{c}95 \% \\
\text { Confidence } \\
\text { Interval }\end{array}$} & \multirow[t]{2}{*}{ Minimum } & \multirow[t]{2}{*}{ Maximum } & \multirow[t]{2}{*}{$p$-value } \\
\hline & & $\begin{array}{r}\text { Lower } \\
\text { Limit } \\
\end{array}$ & $\begin{array}{l}\text { Upper } \\
\text { Limit } \\
\end{array}$ & & & \\
\hline $\begin{array}{l}\text { Transbond } \\
\boldsymbol{X T}(n=20)\end{array}$ & \begin{tabular}{|c|}
2.28 \\
\pm \\
0.44
\end{tabular} & \multirow{2}{*}{2.22} & \multirow{2}{*}{3.02} & 1.41 & 3.17 & \multirow{2}{*}{$<0.001$} \\
\hline Cyanoacrylate $(n=20)$ & \begin{tabular}{|c|}
4.90 \\
\pm \\
0.76
\end{tabular} & & & 3.62 & 7.01 & \\
\hline
\end{tabular}

\section{DISCUSSION}

As the use of skeletal anchorage miniplates has become consolidated as a technique, new versions of these devices modified to accept orthodontic accessories such as coils, elastics, and wires have been developed [7, 11 - 13]. However, achieving the desired orthodontic mechanics depends on proper miniplate positioning during the surgical procedure. Operator experience [14], patient anatomy, and the quality of bone at the site of miniplate fixation $[15,16]$ must all be taken into account. Hence, the position actually possible for each miniplate may not be optimal for achieving orthodontic tooth movement. In addition, anchor points may need to be modified to accomplish new mechanics. Within this context, the bonding of orthodontic accessories to miniplates can facilitate treatment by providing new possibilities of orthodontic movement while avoiding further surgical interventions for miniplate repositioning. The mechanical test conducted in this study corroborates current clinical practice, in which orthodontic accessories are commonly bonded to miniplates as a means of assisting treatment planning [9] and providing additional opportunities for orthodontic mechanics to meet the needs of each case.

Several varieties of miniplates are available on the market. The miniplate head (i.e., the portion that remains exposed within the oral cavity) is available in several shapes, including circular [4], hook $[9,13]$ and tube $[6,17,18]$. Although there have been no previous studies on the bonding of orthodontic accessories to miniplates, it has been observed that such attachment is possible regardless of miniplate shape. For the present study, the miniplate model used by Umemori et al. [5], has been chosen, as it is readily available on the market and its cost is relatively low.

Temporary anchorage devices have greatly expanded treatment possibilities. These devices can be used for compensation of surgical cases [7] and as management adjuncts in surgery-first approaches [11]. Orthodontists can bond active components of orthodontic appliances (wires and springs) directly to the exposed portion of miniplates [11]. However, this does not solve the problem of occasionally having to move the point of anchorage, and practitioners are still limited to using the systems made by the miniplate manufacturer. Bonding of orthodontic devices to anchorage miniplates can provide additional torque for dental intrusion, facilitate treatment, and shorten orthodontic appliance wear time $[9,11]$.
The concept of optimal (or ideal) orthodontic force is based on the hypothesis that a force of a given magnitude and time course (continuous vs. intermittent or constant $v s$. decreasing, etc.) can achieve maximum tooth movement with maximum patient comfort and no damage to periodontal tissues. This force may differ in each tooth and each patient [19]. There is no consensus on the optimal orthodontic force in the literature [20]. Furthermore, forces are commonly understood and expressed in grams (g), an erroneous practice, as the gram is a unit of mass rather than force. De Clerck et al. [6]. used a force reported as $50-100 \mathrm{~g}$ on a temporary skeletal anchorage miniplate secured with 3 screws for distalization of 27 canines, and achieved a mean movement of $1.14 \mathrm{~mm}$ per month. Kaya et al., [21]. Compared the zygoma anchorage system to cervical headgear, with a force of $450 \mathrm{~g}$ applied in both groups. The forces employed when mini-implants are used as temporary anchorage for orthodontic tooth movement range widely; $175 \mathrm{~g}$ [22], 30-200 g [23, 24], $180 \mathrm{~g}$ [25], and up to $300-1000 \mathrm{~g}$ [26] have been reported. The research question of the present study was: is the bond between orthodontic accessory and miniplate strong enough to accomplish tooth movement? The mean debonding shear strength of orthodontic accessories in the tested specimens was $4.90 \mathrm{MPa}$ in the cyanoacrylate group and $2.28 \mathrm{MPa}$ in the Transbond XT group. Even the lowest values found in each of these groups (1.42 $\mathrm{MPa}$ in Group 1 and 3.62 MPa in Group 2) exceeded the forces needed for tooth movement.

Cyanoacrylate (CA) instant adhesive was chosen for its low cost, widespread empirical use in clinical practice [27], and long history of use in surgical procedures without causing harm to patients [28 - 30]. Medium-thick CA adhesive was chosen because its greater viscosity reduces the risk of inadvertent bonding at areas other than the desired site (i.e., where the miniplate emerges into the oral cavity). Transbond XT was developed for orthodontic use. Is one of the most widely used composite resins for bonding of orthodontic appliances [31, 32]. Can be regarded as one of standard adhesive systems in orthodontics. It has been the subject of many studies [32 - 34]. Transbond XT is Bis-GMA based composite without the intermediate low-viscosity resin can guarantee clinically acceptable bond strength to acid-etched enamel, it would be advantageous for orthodontic bracket bonding by reducing the number of steps during bonding and the potential for error through contamination during the bonding procedure [35].

The in vitro nature of this trial carries limitations, including the clean, moisture-free conditions under which bonding was performed and the fact that all procedures were done by the same operator. In the clinical setting, where moisture is present, relative isolation is mandatory to facilitate bonding of the accessory to the miniplate. Under the conditions of this experiment, CA adhesive provided greater ease of bonding, as it does not require light curing; however, composite resin provides greater control for device positioning, which may actually translate to greater ease of use. As with other in vitro studies, it was necessary to rely on thermocycling to simulate oral cavity conditions. Also, the stress applied on the bonded of orthodontic devices to anchorage miniplates in clinic is a combination of shear, tensile and torsion forces. This could be 
considered the main limitation of this study.

\section{CONCLUSION}

Therefore, bonding of orthodontic devices (such as tubes) to miniplates enhances the versatility of treatment. The results of this study corroborate current clinical practice. In addition, the fact that conventional rigid internal fixation miniplates were used reduces cost and facilitates standardization by dental practitioners. In both groups, debonding strength exceeded which is necessary for orthodontic tooth movement. Thus, if there is a need to change orthodontic mechanics during treatment, both bonding agents can be expected to behave effectively, despite the significant different between groups.

\section{ETHICS APPROVAL AND CONSENT TO PARTICIPATE}

The study was approved by the Ethics Committee of The Pontifical Catholic University of Rio Grande do Sul (Code \# 2936).

\section{HUMAN AND ANIMAL RIGHTS}

No animals/humans were used in the study that are the basis of this research.

\section{CONSENT FOR PUBLICATION}

Not applicable.

\section{AVAILABILITY OF DATA AND MATERIAL}

The data supporting the findings of the article is available in the BIBLIOTECA PUCRS at [https://biblioteca.pucrs.br], reference number [01000480637].

\section{FUNDING}

None.

\section{CONFLICT OF INTEREST}

The authors declare no conflict of interest, financial or otherwise.

\section{ACKNOWLEDGEMENTS}

Declared none.

\section{REFERENCES}

[1] Gray JB, Steen ME, King GJ, Clark AE. Studies on the efficacy of implants as orthodontic anchorage. Am J Orthod 1983; 83(4): 311-7. [http://dx.doi.org/10.1016/0002-9416(83)90226-9] [PMID: 6573144]

[2] Jenner JD, Fitzpatrick BN. Skeletal anchorage utilising bone plates. Aust Orthod J 1985; 9(2): 231-3.

[PMID: 3870084]

[3] Turley PK, Kean C, Schur J, et al. Orthodontic force application to titanium endosseous implants. Angle Orthod 1988; 58(2): 151-62. [PMID: 3164593]

[4] Cornelis MA, Scheffler NR, De Clerck HJ, Tulloch JF, Behets CN. Systematic review of the experimental use of temporary skeletal anchorage devices in orthodontics. Am J Orthod Dentofacial Orthop 2007; 131(4)(Suppl.): S52-8.

[http://dx.doi.org/10.1016/j.ajodo.2006.05.033] [PMID: 17448386]

[5] Umemori M, Sugawara J, Mitani H, Nagasaka H, Kawamura H. Skeletal anchorage system for open-bite correction. Am J Orthod Dentofacial Orthop 1999; 115(2): 166-74.

[http://dx.doi.org/10.1016/S0889-5406(99)70345-8] [PMID: 9971928]
[6] De Clerck H, Geerinckx V, Siciliano S. The zygoma anchorage system. J Clin Orthod 2002; 36(8): 455-9.

[PMID: 12271935]

[7] Chung KR, Kim YS, Linton JL, Lee YJ. The miniplate with tube for skeletal anchorage. J Clin Orthod 2002; 36(7): 407-12.

[PMID: 12165982]

[8] Sherwood KH, Burch JG. Skeletally based miniplate supported orthodontic anchorage. J Oral Maxillofac Surg 2005; 63(2): 279-84. [http://dx.doi.org/10.1016/j.joms.2003.06.020] [PMID: 15690303]

[9] Nishimura M, Sannohe M, Nagasaka H, Igarashi K, Sugawara J. Nonextraction treatment with temporary skeletal anchorage devices to correct a class II division 2 malocclusion with excessive gingival display. Am J Orthod Dentofacial Orthop 2014; 145(1): 85-94. [http://dx.doi.org/10.1016/j.ajodo.2012.06.022] [PMID: 24373658]

[10] Menezes LM, Chevitarese O. Influência da contaminação salivar e do recondicionamento da superfície do esmalte contaminado sobre a resistência da colagem ao cisalhamento. 1993.

[11] Sugawara J. Temporary skeletal anchorage devices: The case for miniplates. Am J Orthod Dentofacial Orthop 2014; 145(5): 559-65 [http://dx.doi.org/10.1016/j.ajodo.2014.03.010] [PMID: 24785919]

[12] Chung KR, Kim SH, Mo SS, Kook YA, Kang SG. Severe class II division 1 malocclusion treated by orthodontic miniplate with tube. Prog Orthod 2005; 6(2): 172-86.

[PMID: 16276427]

[13] Lara JC, Facio Umaña JA. Modified miniplates for orthopaedic skeletal anchorage. Int J Oral Maxillofac Surg 2012; 41(5): 566-8. [http://dx.doi.org/10.1016/j.ijom.2012.02.006] [PMID: 22391107]

[14] Lee SJ, Lin L, Kim SH, Chung KR, Donatelli RE. Survival analysis of a miniplate and tube device designed to provide skeletal anchorage. Am J Orthod Dentofacial Orthop 2013; 144(3): 349-56. [REMOVED HYPERLINK FIELD].

[http://dx.doi.org/10.1016/j.ajodo.2013.03.026] [PMID: 23992807]

[15] Huang YW, Chang CH, Wong TY, Liu JK. Bone stress when miniplates are used for orthodontic anchorage: Finite element analysis. Am J Orthod Dentofacial Orthop 2012; 142(4): 466-72. [http://dx.doi.org/10.1016/j.ajodo.2012.04.019] [PMID: 22999669]

[16] Motoyoshi M, Inaba M, Ono A, Ueno S, Shimizu N. The effect of cortical bone thickness on the stability of orthodontic mini-implants and on the stress distribution in surrounding bone. Int $\mathrm{J}$ Oral Maxillofac Surg 2009; 38(1): 13-8.

[http://dx.doi.org/10.1016/j.ijom.2008.09.006] [PMID: 18963818]

[17] Sugawara J, Kanzaki R, Takahashi I, Nagasaka H, Nanda R. Distal movement of maxillary molars in nongrowing patients with the skeletal anchorage system. Am J Orthod Dentofacial Orthop 2006; 129(6): 723-33.

[http://dx.doi.org/10.1016/j.ajodo.2005.08.036] [PMID: 16769490]

[18] Chung KR, Kim SH, Kang YG, Nelson G. Orthodontic miniplate with tube as an efficient tool for borderline cases. Am J Orthod Dentofacial Orthop 2011; 139(4): 551-62.

[http://dx.doi.org/10.1016/j.ajodo.2008.08.041] [PMID: 21457867]

[19] Proffit WR, Fields HW, Sarver DM. Contemporary orthodontics. $5^{\text {th }}$ ed. St Louis, Mo: Elsevier/Mosby 2013; pp. 265-97.

[20] Ren Y, Maltha JC, Kuijpers-Jagtman AM. Optimum force magnitude for orthodontic tooth movement: A systematic literature review. Angle Orthod 2003; 73(1): 86-92.

[PMID: 12607860]

[21] Kaya B, Arman A, Uçkan S, Yazici AC. Comparison of the zygoma anchorage system with cervical headgear in buccal segment distalization. Eur J Orthod 2009; 31(4): 417-24. [http://dx.doi.org/10.1093/ejo/cjp016] [PMID: 19509344]

[22] Gedrange T, Köbel C, Harzer W. Hard palate deformation in an animal model following quasi-static loading to stimulate that of orthodontic anchorage implants. Eur J Orthod 2001; 23(4): 349-54.

[http://dx.doi.org/10.1093/ejo/23.4.349] [PMID: 11544784]

[23] Tseng YC, Hsieh CH, Chen CH, Shen YS, Huang IY, Chen CM. The application of mini-implants for orthodontic anchorage. Int $\mathbf{J}$ Oral Maxillofac Surg 2006; 35(8): 704-7.

[http://dx.doi.org/10.1016/j.ijom.2006.02.018] [PMID: 16690253]

[24] Park HS, Kyung HM, Sung JH. A simple method of molar uprighting with micro-implant anchorage. J Clin Orthod 2002; 36(10): 592-6. [PMID: 12428309]

[25] Hedayati Z, Hashemi SM, Zamiri B, Fattahi HR. Anchorage value of surgical titanium screws in orthodontic tooth movement. Int J Oral Maxillofac Surg 2007; 36(7): 588-92.

[http://dx.doi.org/10.1016/j.ijom.2006.10.020] [PMID: 17524619]

[26] Wehrbein H, Glatzmaier J, Yildirim M. Orthodontic anchorage capacity of short titanium screw implants in the maxilla. An 
experimental study in the dog. Clin Oral Implants Res 1997; 8(2): $131-41$

[http://dx.doi.org/10.1034/j.1600-0501.1997.080208.x]

[PMID: 9758964]

[27] Endo MS, Costa JV, Natali MR, Alfredo Franco Queiroz AF. Efeito in vivo do etil-cianoacrilato como isolamento absoluto em gengiva. Rev Odontol UNESP 2007; 36(3): 287-92.

[28] Sagar P, Prasad K, Lalitha RM, Ranganath K. Cyanoacrylate for intraoral wound closure: A possibility? Int J Biomater 2015; 2015165428

[http://dx.doi.org/10.1155/2015/165428] [PMID: 26649041]

[29] Choi BH, Kim BY, Huh JY, et al. Cyanoacrylate adhesive for closing sinus membrane perforations during sinus lifts. J Craniomaxillofac Surg 2006; 34(8): 505-9.

[http://dx.doi.org/10.1016/j.jcms.2006.07.859] [PMID: 17157515]

[30] Kahraman N, Yumun G, Gücü A, et al. Administration of perivascular cyanoacrylate for the prevention of cellular damage in saphenous vein grafts: An experimental model. Cardiovasc J Afr 2016; 27(3): 159-63. [http://dx.doi.org/10.5830/CVJA-2015-078] [PMID: 26506883]
[31] Menini A, Cozzani M, Sfondrini MF, Scribante A, Cozzani P, Gandini P. A 15-month evaluation of bond failures of orthodontic brackets bonded with direct versus indirect bonding technique: A clinical trial. Prog Orthod 2014; 15(1): 70.

[http://dx.doi.org/10.1186/s40510-014-0070-9] [PMID: 25547461]

[32] Jung MH. Survival analysis of brackets and tubes: A twelve-month assessment. Angle Orthod 2014; 84(6): 1034-40.

[http://dx.doi.org/10.2319/122613-946.1] [PMID: 24665886]

[33] Turgut MD, Attar N, Korkmaz Y, Gokcelik A. Comparison of shear bond strengths of orthodontic brackets bonded with flowable composites. Dental Materials J 2011; 30(1): 66-71.

[http://dx.doi.org/10.4012/dmj.2010-102]

[34] Park SB, Son WS, Ko CC, et al. Influence of flowable resins on the shear bond strength of orthodontic brackets. Dent Mater J 2009; 28(6): $730-4$

[http://dx.doi.org/10.4012/dmj.28.730] [PMID: 20019425]

[35] Ryou DB, Park HS, Kim KH, Kwon TY. Use of flowable composites for orthodontic bracket bonding. Angle Orthod 2008; 78(6): 1105-9. [http://dx.doi.org/10.2319/013008-51.1] [PMID: 18947267]

\section{(C) 2019 Haas et al.}

This is an open access article distributed under the terms of the Creative Commons Attribution 4.0 International Public License (CC-BY 4.0), a copy of which is available at: https://creativecommons.org/licenses/by/4.0/legalcode. This license permits unrestricted use, distribution, and reproduction in any medium, provided the original author and source are credited. 